
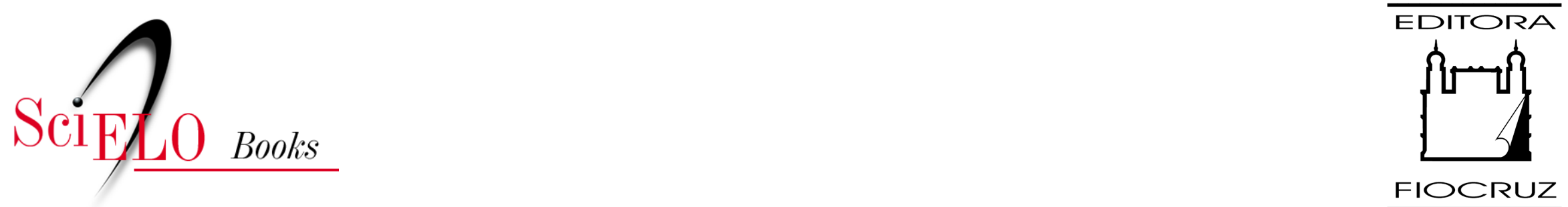

\title{
$\underline{1951-1960}$
}

\author{
Renato da Gama-Rosa Costa \\ Alexandre Jose de Souza Pessoas \\ Benedito Tadeu de Oliveira (coord.)
}

COSTA, R. G. R., and PESSOA, A. J. S. 1951-1960. In.: Um lugar para a ciência: a formação do campus de Manguinhos [online]. Coordinator Benedito Tadeu de Oliveira. Rio de Janeiro: Editora FIOCRUZ, 2003, pp. 134-149. História e saúde collection. ISBN: 978-655708-113-6. https://doi.org/10.7476/9786557081136.0010.

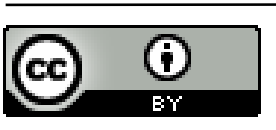

All the contents of this work, except where otherwise noted, is licensed under a Creative Commons Attribution 4.0 International license.

Todo o conteúdo deste trabalho, exceto quando houver ressalva, é publicado sob a licença Creative Commons Atribição 4.0.

Todo el contenido de esta obra, excepto donde se indique lo contrario, está bajo licencia de la licencia Creative Commons Reconocimento 4.0. 


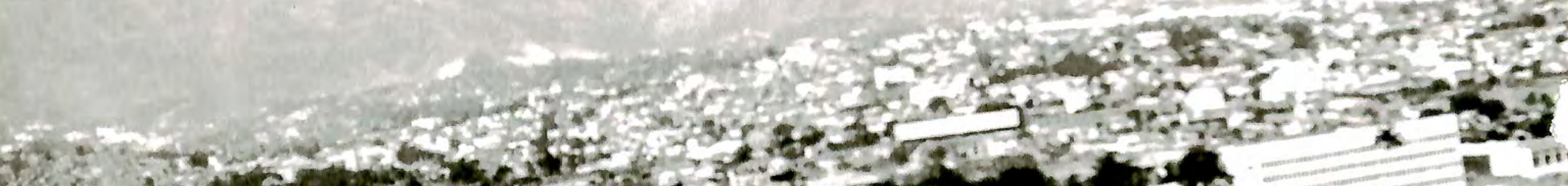

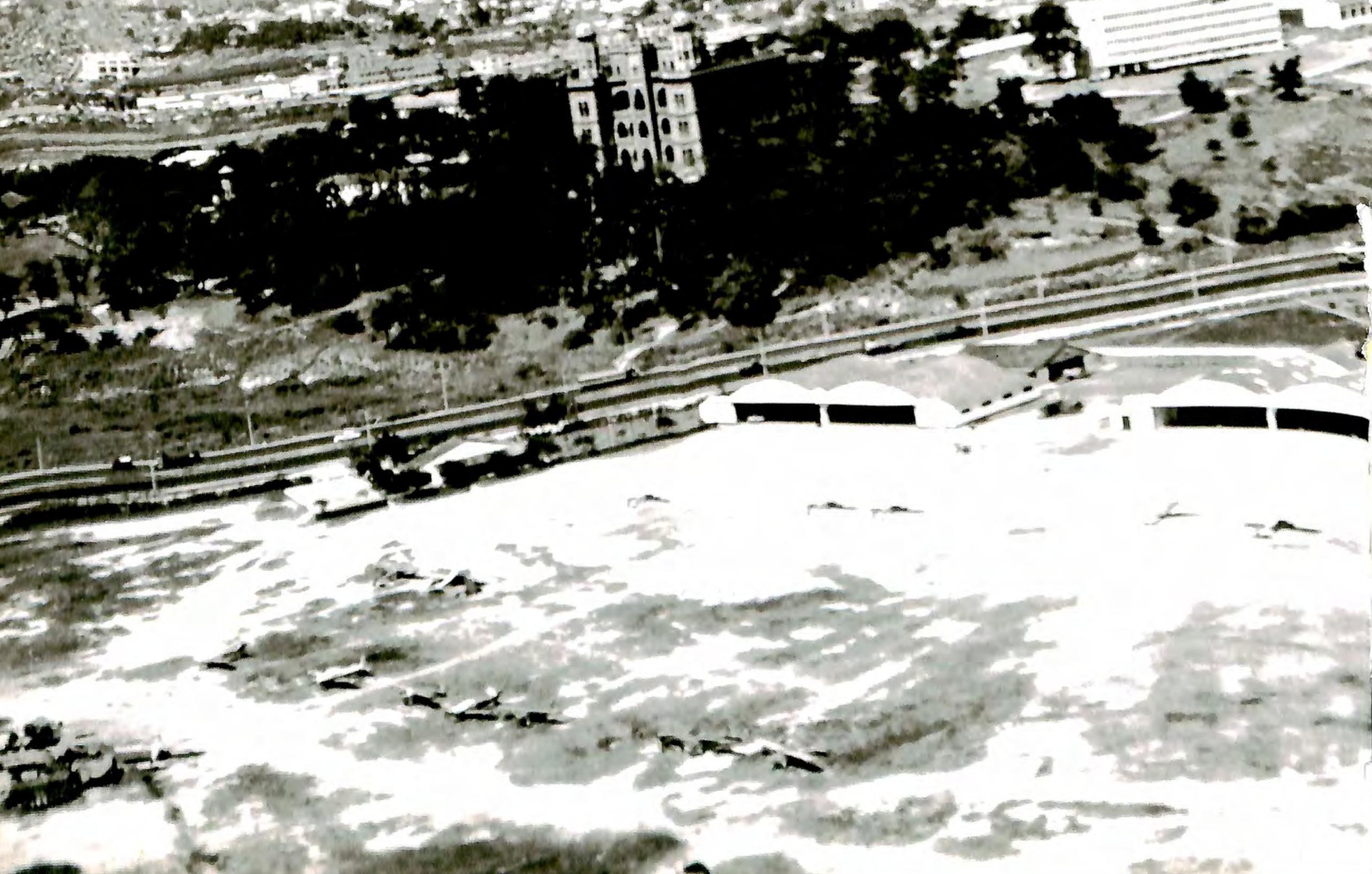



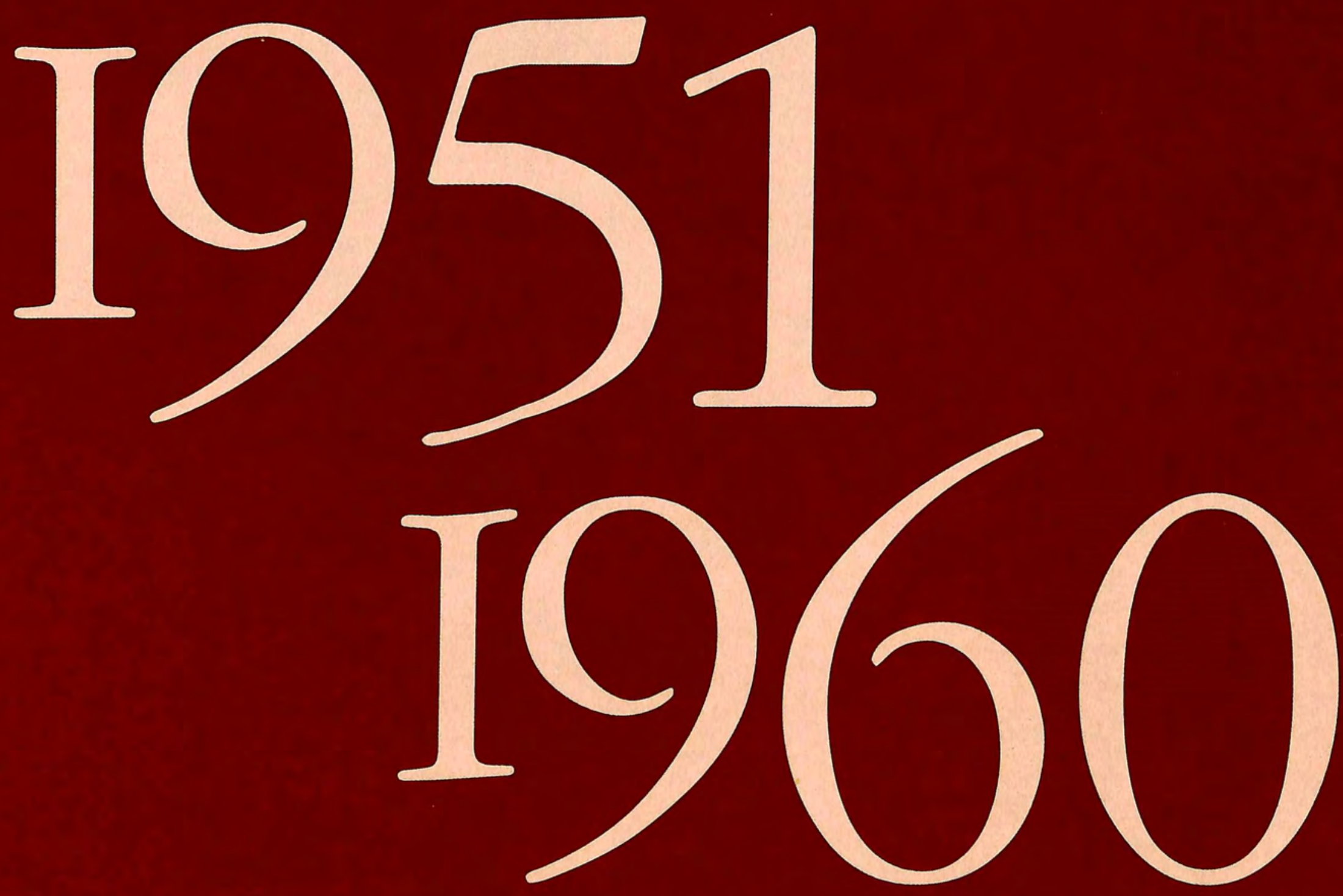

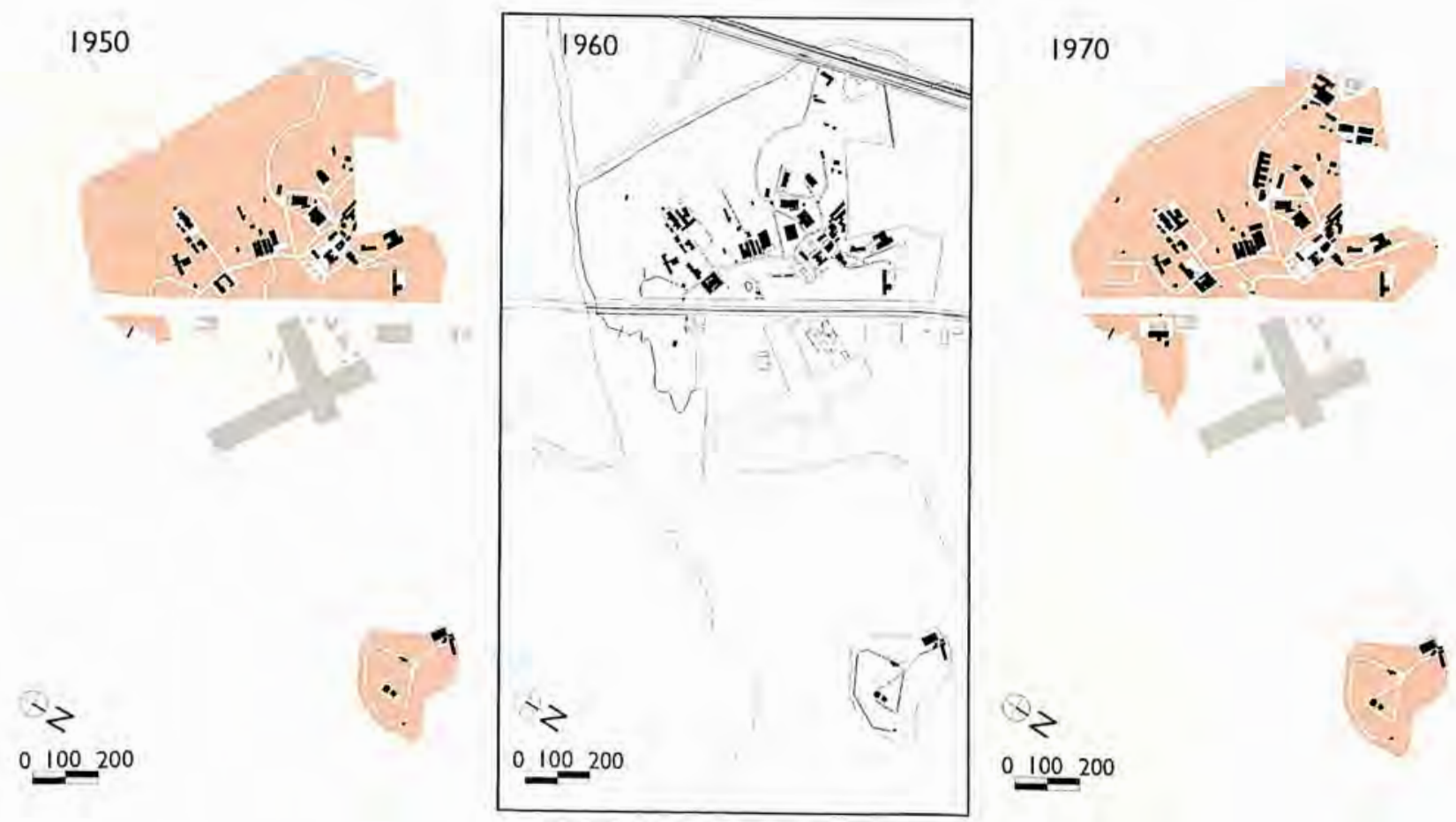

De 1951 a 1960

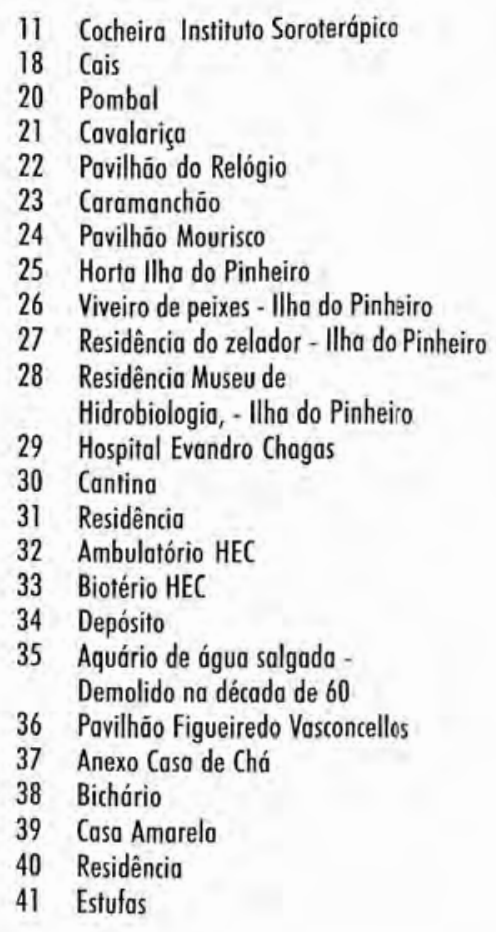

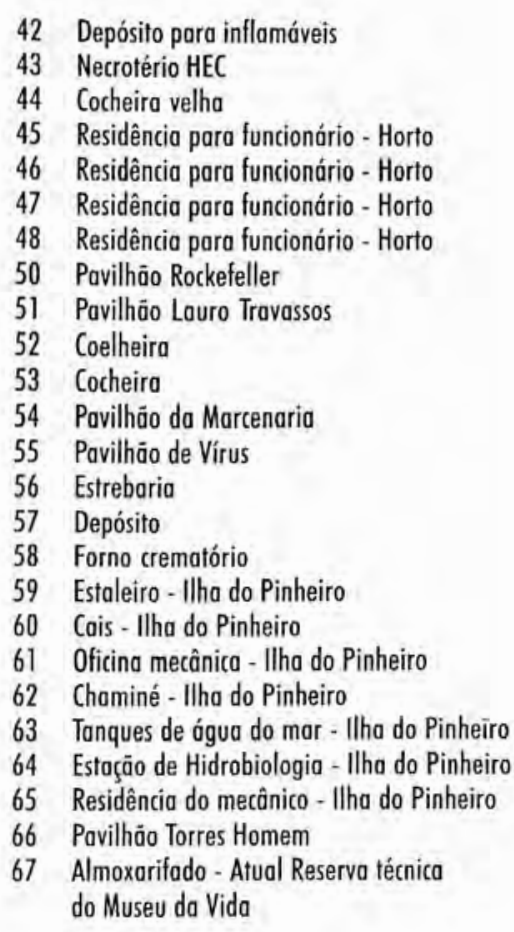

68 Pavilhāo Carlos Chagas

69 Pavilhão Arthur Neiva

70 Pavilhão da Biologia

71 Oficina

72 Goragem

73 Depósito

74 Pavilhão Carlos Augusto Da Silva

75 Lavanderia HEC

76 Pavilhōo Adolfo Lutz

77 Coixa d'águo

78 Depósito

79 Cisterna

80 Canil

81 Galinheiro

82 Portaria Avenida Brasil

83 Pavilhão Henrique Aragão

84 Pavilhāo Leonidas Deane

85 Estação de Tratamento de Esgoto

86 Cocheira

87 Potreiro/cocheiro

88 Brete

89 Depósito de Raçôes

90 Casa de Força

91 Bio-Monguinhos

92 Caixa D'ógua

93 Casa de Força 

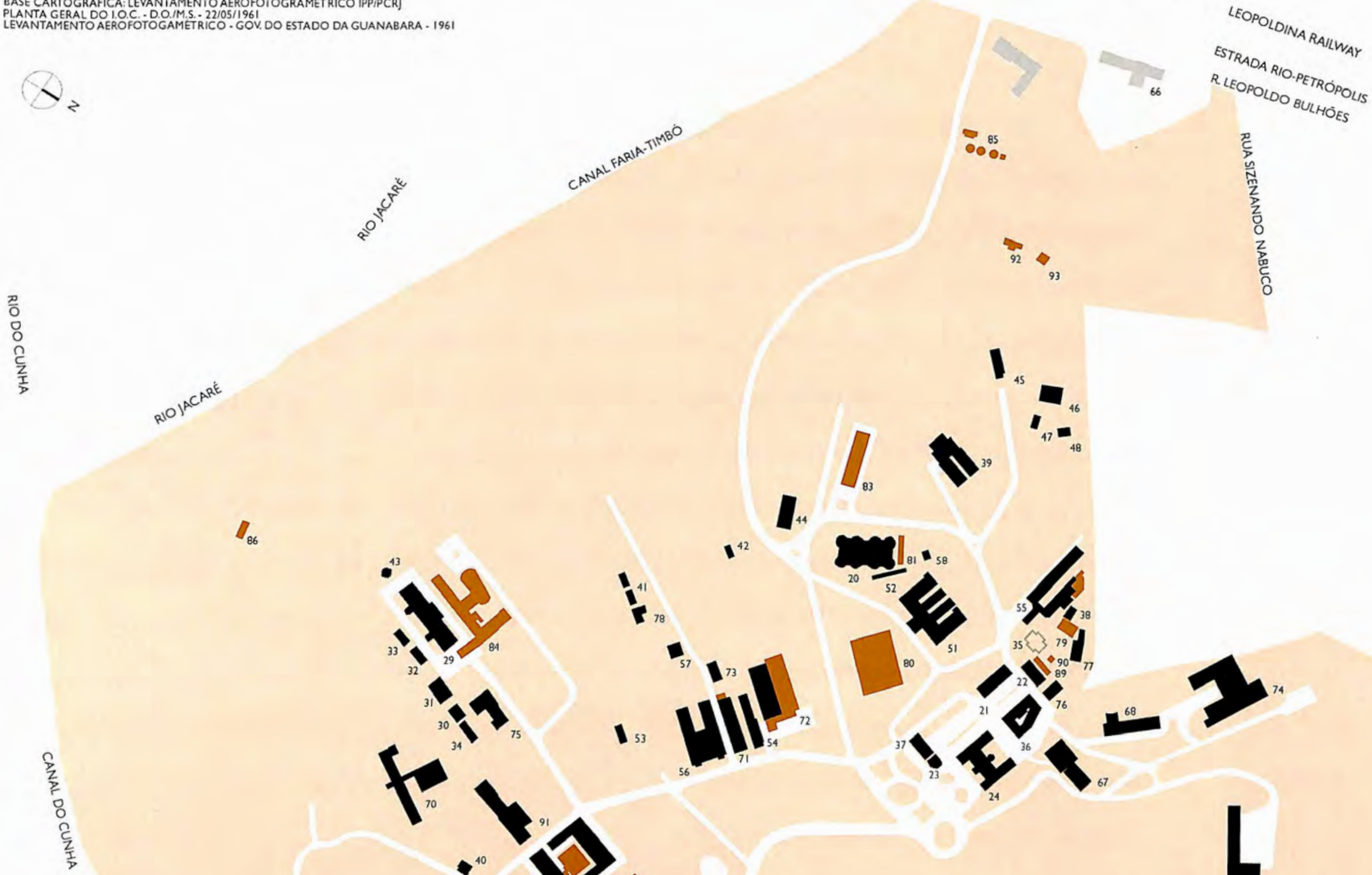

86

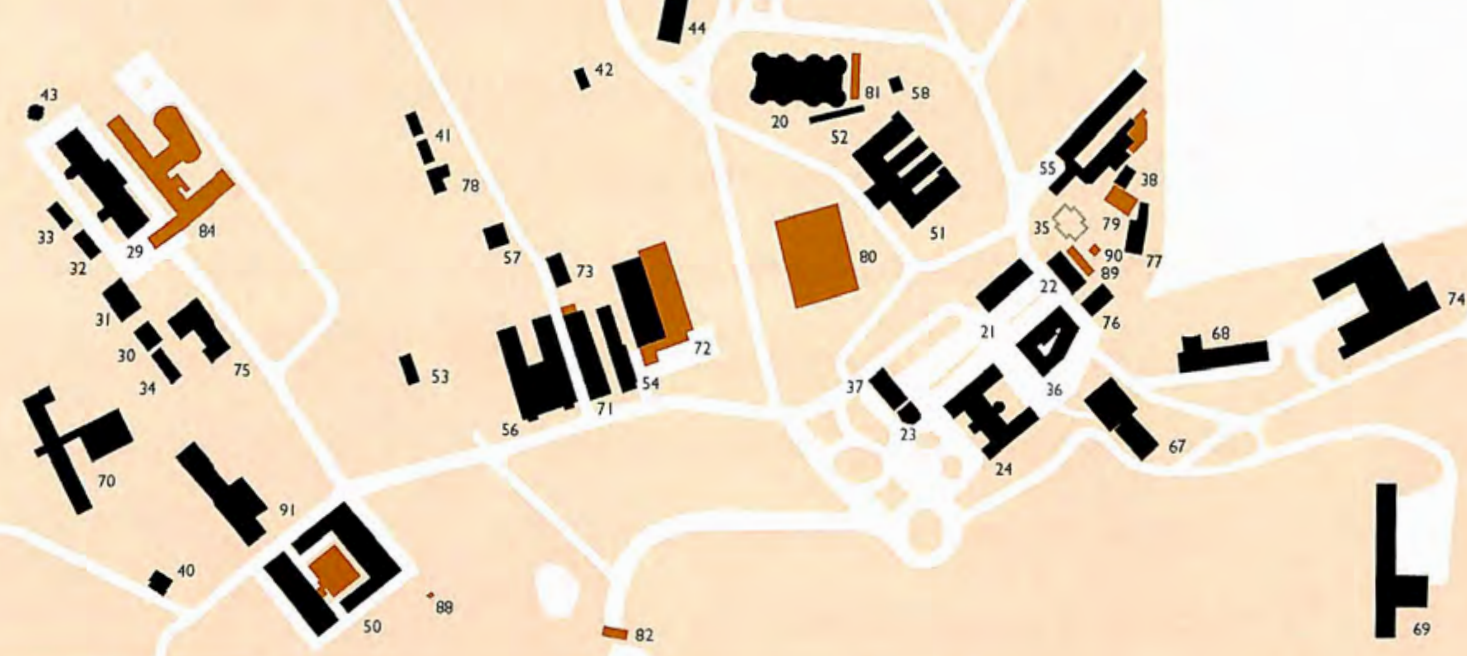

Terreno da Fiocruz

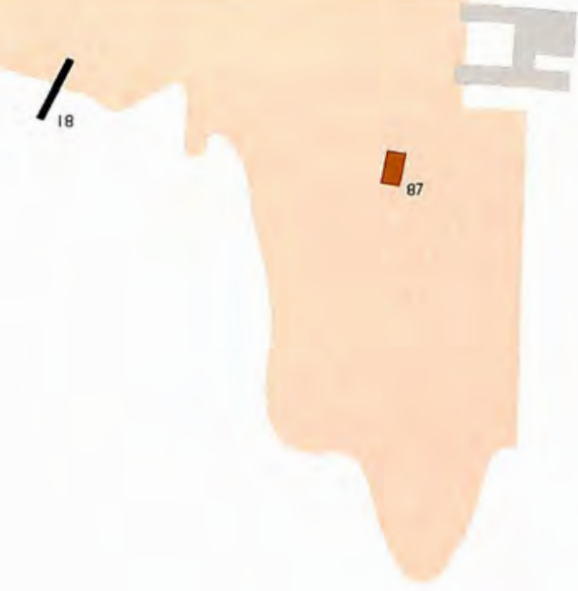

OFICINA DA

DO MINISTERIO DA
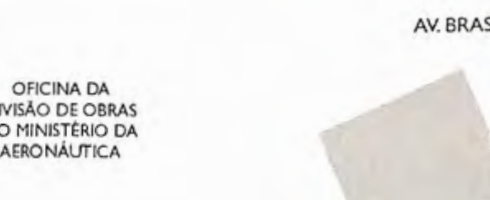

BRASIL
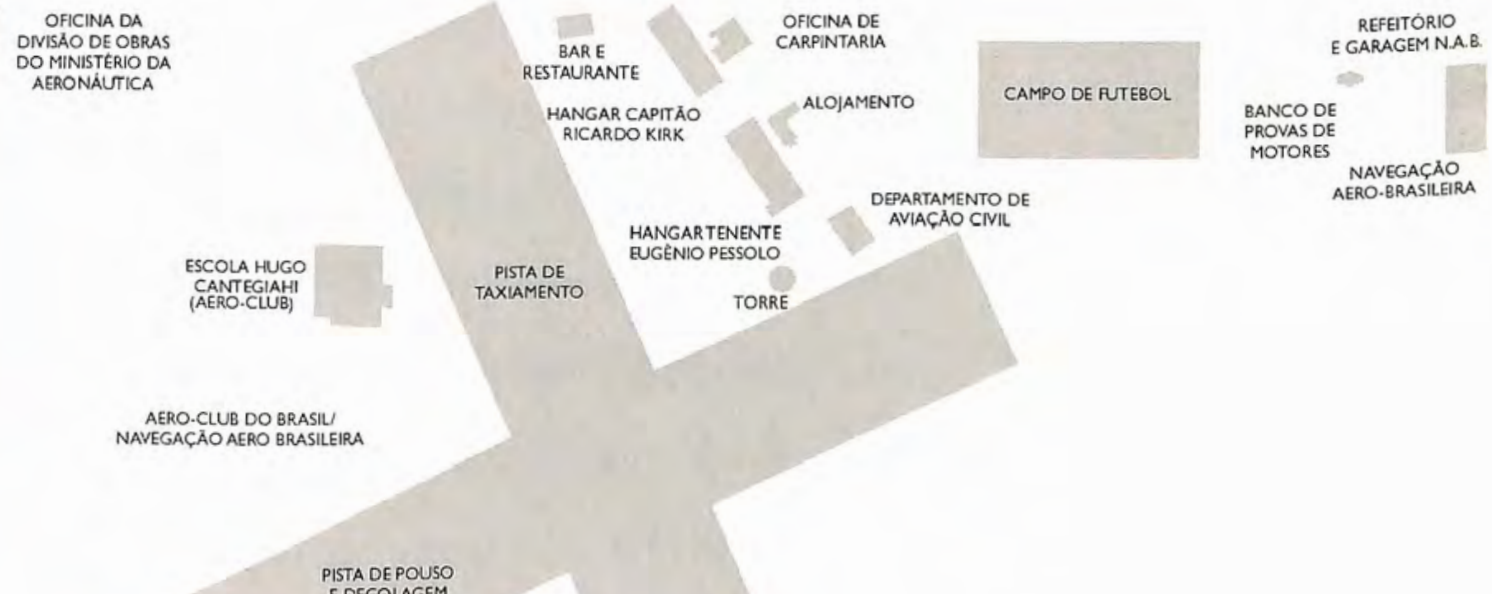

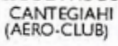
ARTAMENTO D NAVEGACAO
AERO-BRASILERA AERO.CLUB DO BRASIL 
D

epois da direção de Henrique Aragão, a última gestão vitalícia, o IOC passou por gestões curtas e descontínuas, incapazes de elaborar e de concretizar projetos de longo prazo. Em 1953, o IOC vinculou-se diretamente ao Ministério da Saúde, recém-separado do Ministério da Educação. O Instituto Oswaldo Cruz voltou a ser mais dependente politicamente do governo, reduzindo sua autonomia à produção de soros e vacinas, e as outras atividades passaram ao controle do Ministério. O anseio, por parte dos cientistas, era a criação do Ministério da Ciência e Tecnologia.

Em 1952 foi assinado um convênio entre o Serviço Especial de Saúde Pública (Sesp) e o Serviço Nacional de Febre Amarela (SNFA) para a construção de um laboratório para a preparação de vacinas contra febre amarela e varíola.

O primeiro terreno escolhido para o novo laboratório era situado na Rua Visconde de Santa Isabel, no bairro de Vila Isabel, junto ao número 222. As obras já tinham sido iniciadas quando o diretor do Instituto na época, o Dr. Francisco da Silva Laranja Filho, opôs-se à idéia, e assim o laboratório passou a ser construído no terreno do IOC, dando origem a um termo aditivo ao contrato original.

O projeto foi desenvolvido na Seção de Arquitetura da Divisão de Engenharia do próprio Sesp ${ }^{75}$ pelo arquiteto Roberto Nadalutti (Anexo I), funcionário do órgão naquela época.

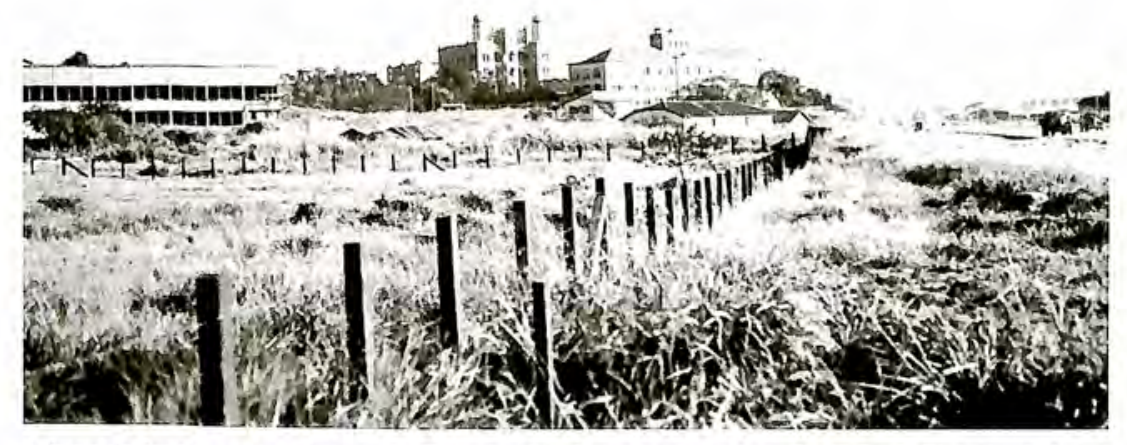

A Avenida Brasil, recém-inaugurada. Em primeiro plano, à esquerda, o Pavilhão da Biologia ainda em construção. Ao fundo, o Pavilhão Rockefeller e atrás o Pavilhāo Mourisco. (c. 1950. DAD/Fiocruz)

\footnotetext{
75 Nadalutti acompanharia a fiscalização posteriormente mesmo depois de deixar o Sesp em 1953, recebendo honorários no valor de $\mathrm{Cr} \$ 40.000,00$, segundo documento Termo de Encerramento e Sumário Final do Projeto $n S U=R J A=6 C$ (Fundo Serviço Especial de Saúde Pública - Acervo DAD/Fiocruz).
} 


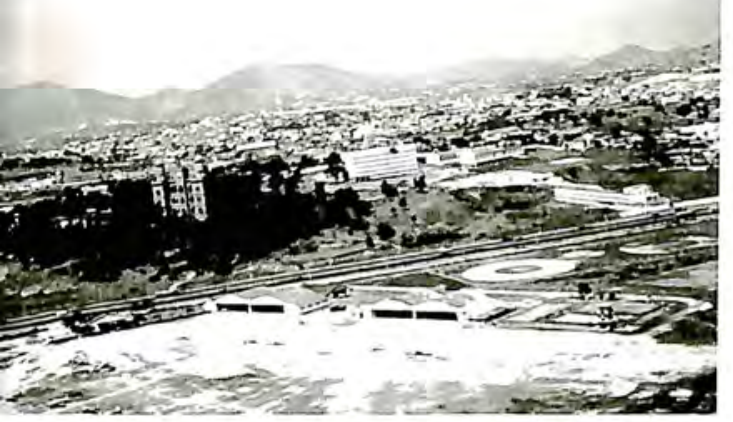

A Avenida Brasil, recém-inaugurada, limita definitivamente a área do campus de Manguinhos, cortando sua comunicação com o mar. Ao mesmo tempo possibilita novos acessos ao Instituto. Já se nota o grande contraste das construçōes de estilo modernista com o conjunto arquitetônico histórico. (DAD/Fiocruz)
O projeto inicial, elaborado por Nadalutti para o terreno de Vila Isabel e implantado parcialmente no campus de Manguinhos, previa um edifício em dois blocos, interligados por uma passarela. No bloco principal, composto de um pavimento térreo e um superior, funcionariam as salas de laboratório propriamente ditas, enquanto o bloco secundário, com apenas um pavimento, abrigaria a garagem, as oficinas de mecânica e carpintaria, bem como um

depósito, uma cozinha e um refeitório. A mudança de terreno causou atrasos das novas obras, que só foram iniciadas em 1954, e a empreiteira contratada para a execução do projeto não aceitou manter o valor inicial destinado em contrato, desistindo da construção do bloco secundário e entregando as instalações incompletas. As obras foram parcialmente concluídas em Oficinas e Garagem recém-concluidas e, ao fundo, o edificio destinado a substituiro antigo Hospital Oswaldo Cruz, em obras. (DAD/Fiocruz)

1956, já a cargo da Divisão de Obras do Ministério da Saúde. ${ }^{76}$ O laboratório só começou a ser usado plenamente em 1960. ${ }^{-7}$ O bloco principal foi pensado como um volume de predominância horizontal,

\footnotetext{
Segundo documentação encontrada no Fundo do Serviço Especial de Saúde Pública do DAD/COC, Fiocruz.
}

Benchimol (2001). 
com fachadas laterais cegas, ao passo que as fachadas principal e posterior foram resolvidas de acordo com a incidência solar. A solução estrutural, que garante forte expressão plástica, é formada por um pórtico, tendo como elemento arquitetônico característico o pilar vazado com a base em forma de V. Esses pilares modulados, além de diminuir o número de apoios, imprimem grande movimentação ao volume estático.

Sobre o projeto comenta Nadalutti:

Foi feito com uma programação muito bem-feita por esse cientista, e isso ajudou muito para que eu fizesse o projeto razoavelmente bem. A intenção naquele tempo era mostrar a estrutura do edifício, então foi feito com aquela estrutura saliente, tem aquele pilar com uma forma vazada no meio, e a intenção foi liberar o espaço interno, porque uma obra dessas tem sempre que sofrer modificações, é como um hospital, é uma função que muda muito, os equipamentos, ainda mais num laboratório daquele tipo, eu imaginava isso; bom, isso aqui vai ser mudado, evidentemente naquele tempo ainda não tinha divisórias, a gente pensava mesmo em alvenaria, mas, enfim, a alvenaria você quebra e muda. Mas a intenção era essa, você poder arrasar tudo aquilo e refazer sem criar problema para o conjunto ${ }^{78}$

A impressão que Nadalutti teve do IOC na época da construçào do Pavilhão de Febre Amarela foi a de configuração do espaço como um campus:

Já se estava querendo fazer ali um projeto urbanístico, esta idéia estava começando (...). O terreno já ficava numa parte plana, o local já era predeterminado, o pessoal disse que aquela era a área que seria possível fazer. Os prédios do lado direito do Castelo (no dente do terreno, em frente à favela) já estavam sendo feitos, mas em volta do Pavilhão de Febre Amarela não havia nada.

O diretor de Saúde naquele tempo apoiou muito a construção, inclusive o méclico cientista que

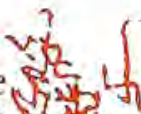
fez o programa era da direção do Instituto. Eu não conhecia a matéria, ele então foi me informandedoun ô

sobre tudo aquilo." um cientista - cuja especialidade era a produção de vacinas contra a febre amatela i", (provavelmente Henrique de Azevedo Penna) -, e ele the forneceu informaçòes essenciais

\footnotetext{
17 Roberto Nadalutti - Trecho de depoimento, de

17 de dezembro de 1998, registrado na fita 1, lado A.

Ver nota 78 .
}

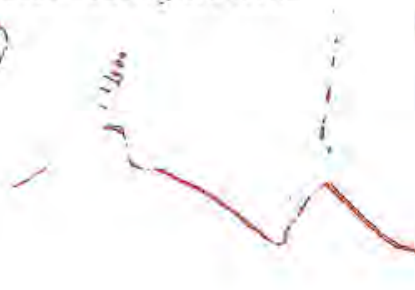




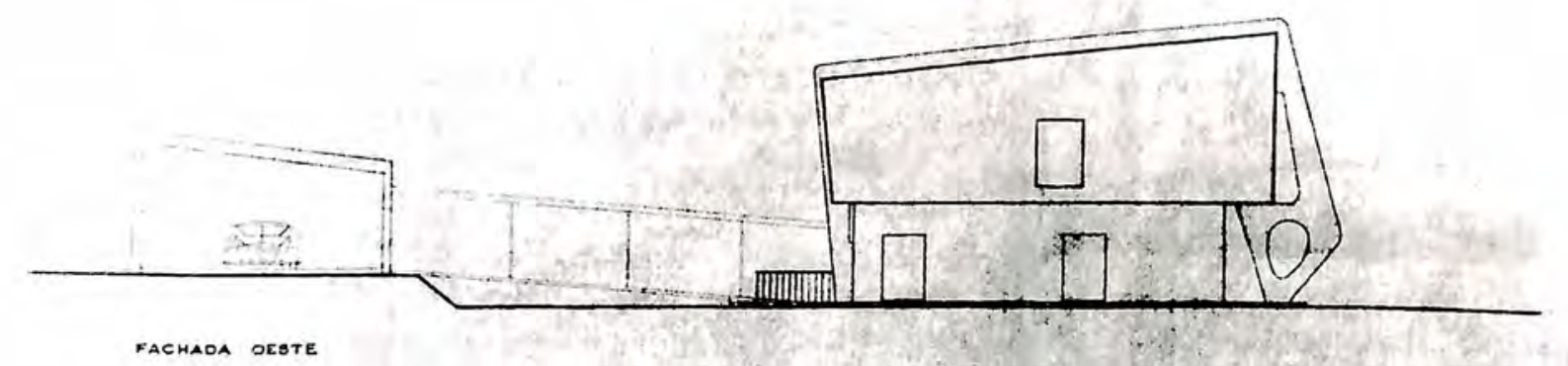

Fachadas do Pavilhão da Febre Amarela, projeto do arquiteto Roberto Nadalutti. 0 projeto inicial previa um bloco posterior de serviços, garagem e refeitório, năo realizado. (DAD/Fiocruz)

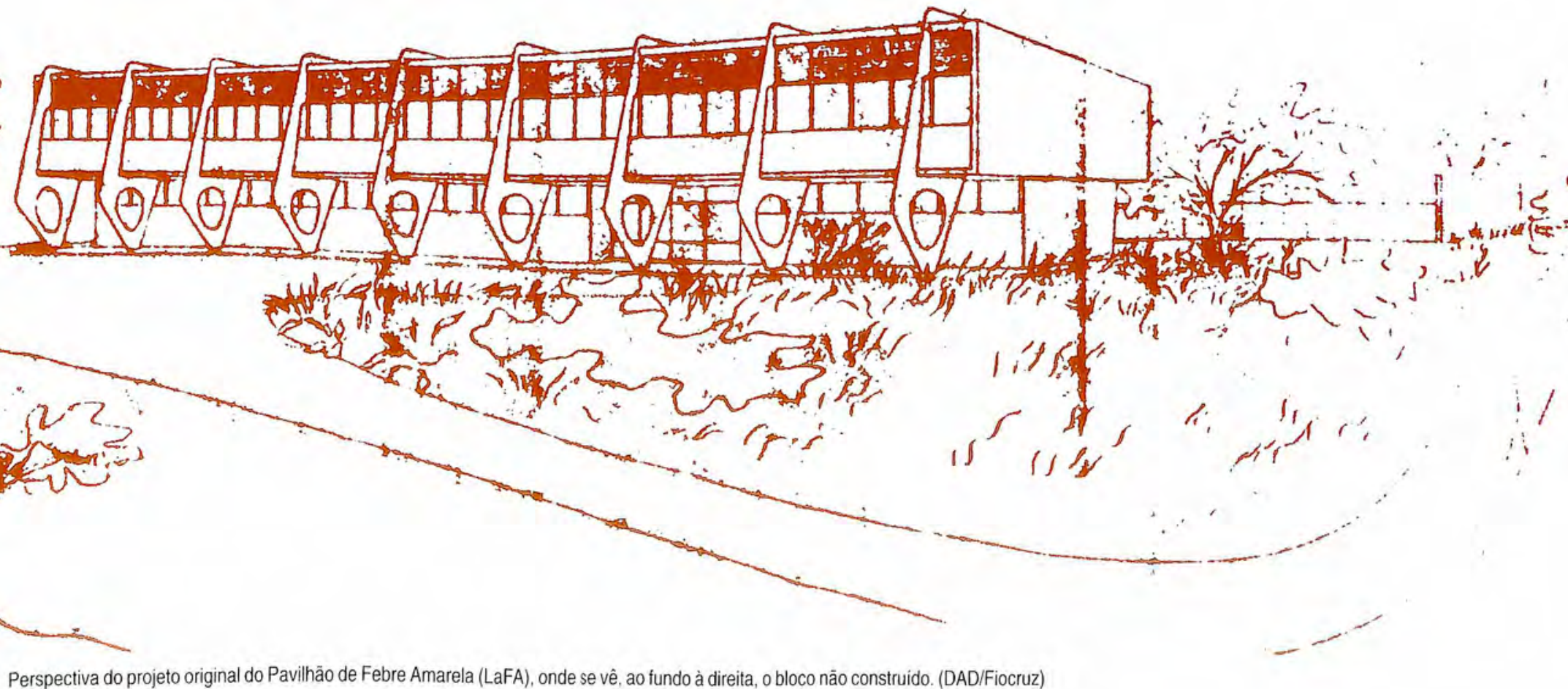


para a organização interna do edifício. A estrutura que funciona como um pórtico foi calculada no Sesp.

Uma das últimas grandes realizações arquitetônicas na década de 50 , dentro do campus de Manguinhos, ainda é reflexo da administraçâo de Gustavo Capanema, como ministro da Saúde e Educação, e de Henrique Aragão, como diretor do IOC. Trata-se do Pavilhào Leônidas Deane, projetado para substituir o antigo Hospital Oswaldo Cruz - atual Evandro Chagas - e que teve sua construção iniciada em 1956. A intençào era que o Hospital Evandro Chagas (chamado de Hospital Oswaldo Cruz até 1941), que descle a década de $30^{50}$ já se revelava um hospital de reduzidas climensòes para as atividades de pesquisas científicas na área da medicina experimental, desse lugar ao novo hospital, com instalações mais modernas e espaços mais amplos. O Pavilhão Leônidas Deane, além de ser concebido com volumes de proporçòes pouco elaboradas, desarmônicas, foi implantado incorretamente. As suas grandes dimensòes sào incompatíveis com a sua localizaçào no alto da colina, bem como a excessiva proximidade com o Hospital Evandro Chagas, uma vez que parte de seu pavimento térreo avança sobre o edifício antigo.

O Pavilhão Leôniclas Deane, de autoria do arquiteto Ramiro Pereira, foi projetado também na Divisão de Obras do Ministério da Educação e Saúcle e teve sua primeira inauguraçào durante a década de 70 , inserido no plano de recuperação do Instituto. Ao longo dos anos sofreu diversas intervencoes para receloer usos váriaclos e foi reinaugurado oficialmente em 2000, com a funçăo de abrigar laboratórios do antigo Instituto Oswaldo Cruz, hoje uma uniclade da Fiocruz.

Nessa década, na gestào de Antônio Augusto Xavier (1955-1958), também foram feitos investimentos em urbanizacào, através da pavimentacào até hoje existente em bloxos de concreto das vias do compus de Manguinhos.

\footnotetext{
No relatório de 1936, constata-se ainda que os equipamentos que deveriam garantir "luz artificial, temperatura e ventilaçâo condicionadas" ao Hospital Oswaldo Cruz numca funcionioram
} 

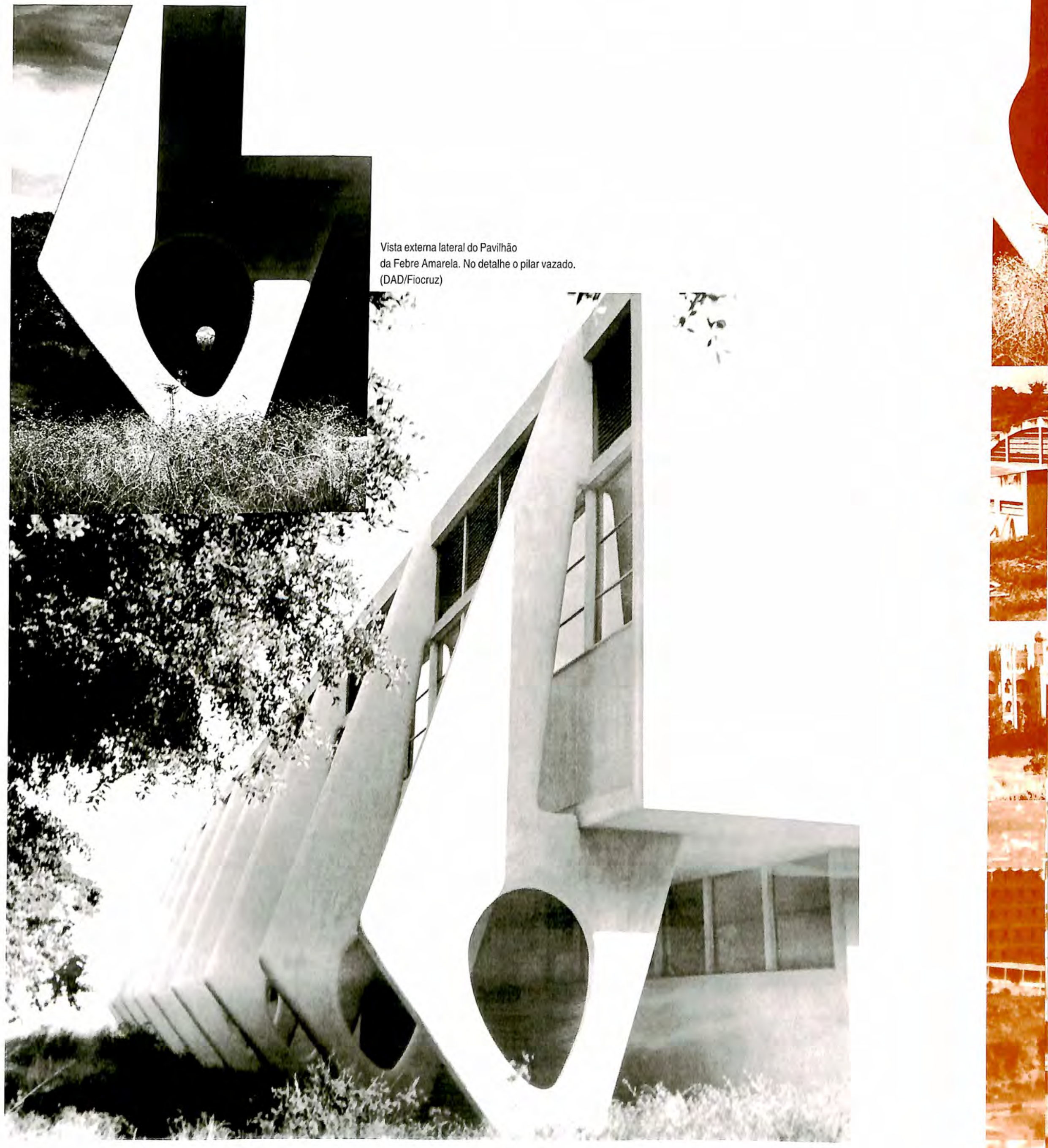

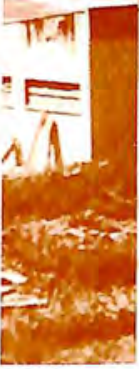
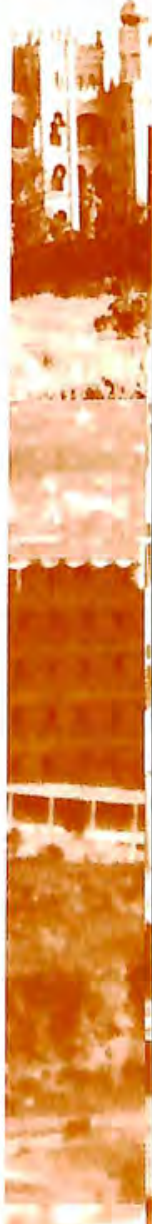


\section{Comenta Albano:}

A única pavimentaçào existente era a que vinha da portaria da Leopolcho Bulhões até a colina principal do Instituto, em paralelepípedo. Apesar das reclamações de quem freqüentava o Instituto, sobre as precárias condições de tráfego pelo terreno, a pavimentação nâo era considerada prioridade pelo diretor Augusto Xavier, que preferia investimentos na construçào e reforma dos laboratórios. Com a verba separada para as obras de pavimentação, o entào diretor da Divisão, o arquiteto Thomaz Estrella, profundo conhecedor do campus do IOC, convidou o ministro da época, após um período de forte chuva, a visitar o Instituto. Dito e feito, o carro atolou bem em frente ao Pavilhào cla Marcenaria, e o ministro, tido como uma pessoa progressista, se convenceu dà pavimentaçào."

Entre os anos 1954 e 1955, foi construícla a portaria da Avenida Brasil, projeto do arquiteto Nabor Forster, também oriundo da Divisão de Obras do Ministério da Educaçào e Saúde. Trata-se de um volume constituído por paredes laterais cegas encimado por uma laje plana em concreto, sustentada por pilares cilíndricos, vazado na sua face lateral esquerda para o ingresso de veículos e que abriga à direita um corpo menor autônomo revestido de pedra, destinado à recepção ao público. A portaria cla Fiocruz, como outros edifícios da mesma época, constitui um singelo marco da arquitetura moderna na Avenida Brasil.

O atual edifício de Bio-Manguinhos, projetado pelo arquiteto Waldyr Ramos, foi constrúdo entre os anos 1956 e 1965, com planimetria retangular, e concebido como um prisma ligeiramente vertical. O edifício tem tratamento sóbrio, com fachaclas laterais cegals e fachadas frontal e posterior rasgadas horizontalmente em cacla pavimento. A estrutura independente é constituícla de pilares circulares aparentes no pavimento térreo, ressaltada pelo uso de pilotis na entrada, que era anteriormente marcada também por uma marquise.

Nesta época propôs-se para o campus de Manguinhos um plano de urbanizaçào de autoria desconhecida. Este plano previa nâo só a construcào de grandes edifícios, à semelhanca dos projetados para os campi das universidades brasileiras, dentro de umá linguagem racionalista moderna, de dois biotérios de forma semelhante ao pombal, como 


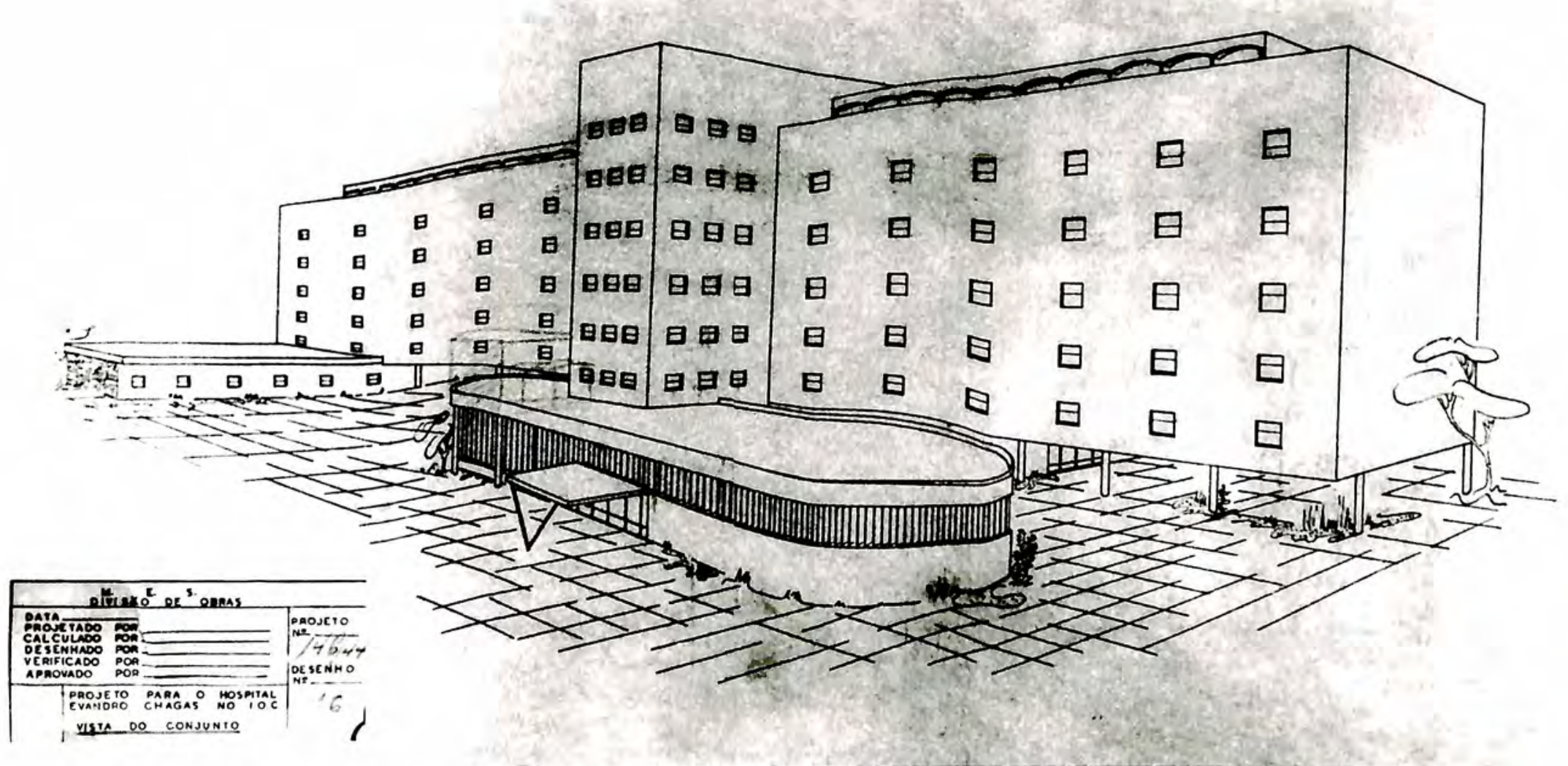

Perspectiva do novo Hospital Oswaldo Cruz, de autoria do arquiteto Ramiro Pereira (atual Pavilhão Leônidas Deane). (DAD/Fiocruz)

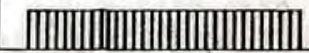

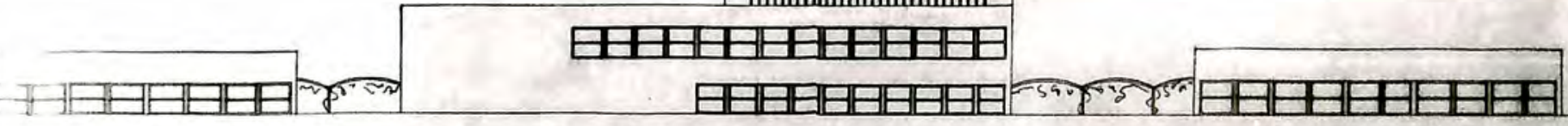

.

F

A

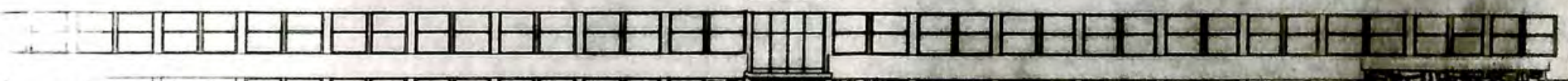

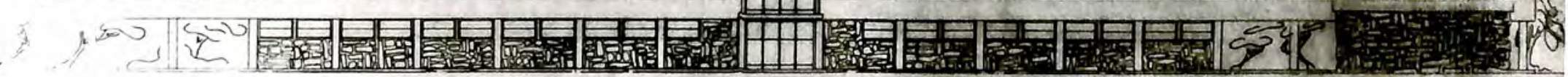

Fachada do novo Hospital Oswaldo Cruz (atual Pavilhāo Leônidas Deane). projeto do arquiteto Ramiro Pereira. (DAD/Fiocruz)

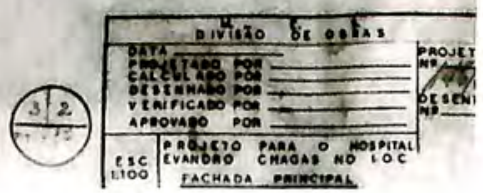


também a demolição de alguns edifícios antigos, como o Hospital Evandro Chagas e as construçôes antigas ao seu redor, ou seja, o Pombal, o Novo Biotério - hoje Pavilhão Lauro Travassos -, a cocheira velha e o edifício das oficinas/estrebaria, além de pequenas residências dos primeiros tempos do Instituto. Desses, apenas as pequenas residências e o edifício das oficinas/estrebaria foram demolidos. Por sorte, esse plano, que causaria grandes danos ao patrimônio da Fiocruz, não foi executado na íntegra. ${ }^{82}$

A construção dos pavilhões de Bio-Manguinhos e Leônidas Deane também passou a interferir na leitura do conjunto arquitetônico histórico de Manguinhos, disputando com a sua silhueta e bloqueando parcialmente algumas das suas principais linhas de visada: aquela dos que trafegam na Avenida Brasil no sentido norte e a dos que vêm pela Rua Leopoldo Bulhồes na direção de Bonsucesso. Com a construção da portaria da Avenida Brasil foi consolidada, a partir de então, essa entrada como a principal do campus. Para a construção da portaria, Luiz Moraes Júnior elaborou um projeto nos moldes daqueles desenvolvidos no início do século XX, o qual não foi realizado. Esse seria seu último contato $^{83}$ com o Instituto, pouco antes da sua morte, em 1955.

Na Divisão de Obras, em meados da década de 50, também foi desenvolvido o projeto das oficinas e da garagem, ampliado posteriormente com projeto de autoria de Waldyr Ramos.

$\mathrm{Na}$ década de 50, algumas construções de apoio, tais como estufa, depósito de inflamáveis, canil, galinheiro, cocheira, potreiro, brete e lavanderia do Hospital Evandro Chagas, foram realizadas. Aconteceram também alguns investimentos em infra-estrutura, com a construção de um reservatório de água e da casa-de-força de eletricidade.

\footnotetext{
82 Segundo mapa encontrado junto ao fundo $10 \mathrm{C}$. Seçōo de Serviços Gerais, Série Administração Geral, Caixa 9, Maço 2, Mapoteca 3, Gaveta 4. (DAD/COC, Fiocruz)$$
{ }^{88} \text { O outro seria o da sobrelevaçâo do Quinino, iá }
$$
citado
} 


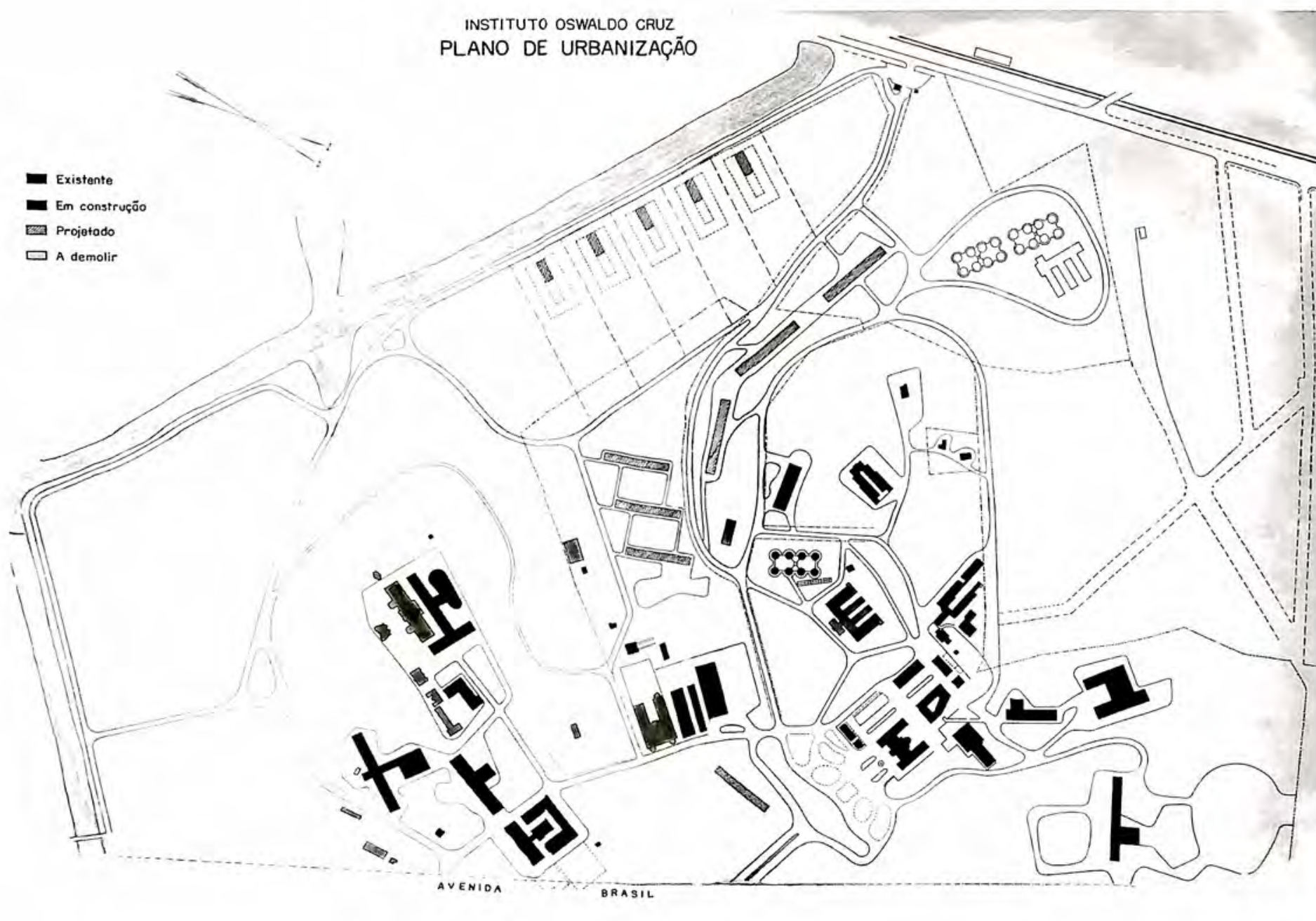

Primeiro planejamento urbano desenvolvido para o campus de Manguinhos. Interessante notar a proposta de demolição do Hospital Evandro Chagas, do Pavilhão Lauro Travassos e do Pombal. Planejava-se também a construção de dois biotérios de forma semelhante ao Pombal (canto superior direito) e de pavilhōes prismáticos sem qualquer orientação solar. (DAD/Fiocruz)
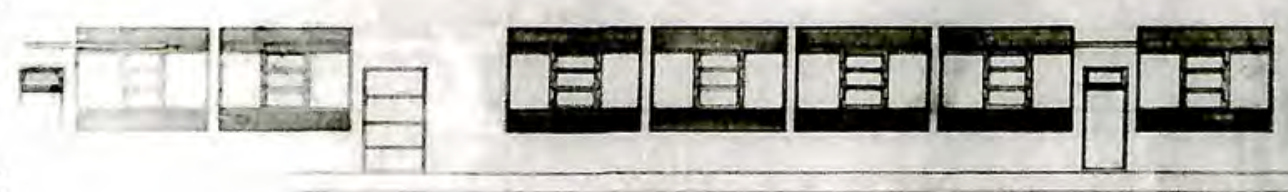

Arean muxins

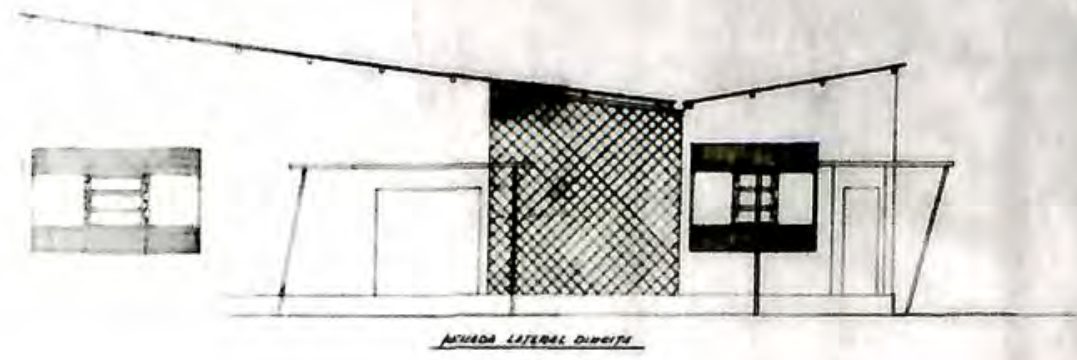

Fachada e planta baixa da Lavanderia, construida como apoio ao Hospital Evandro Chagas. (DAD/Fiocruz) 


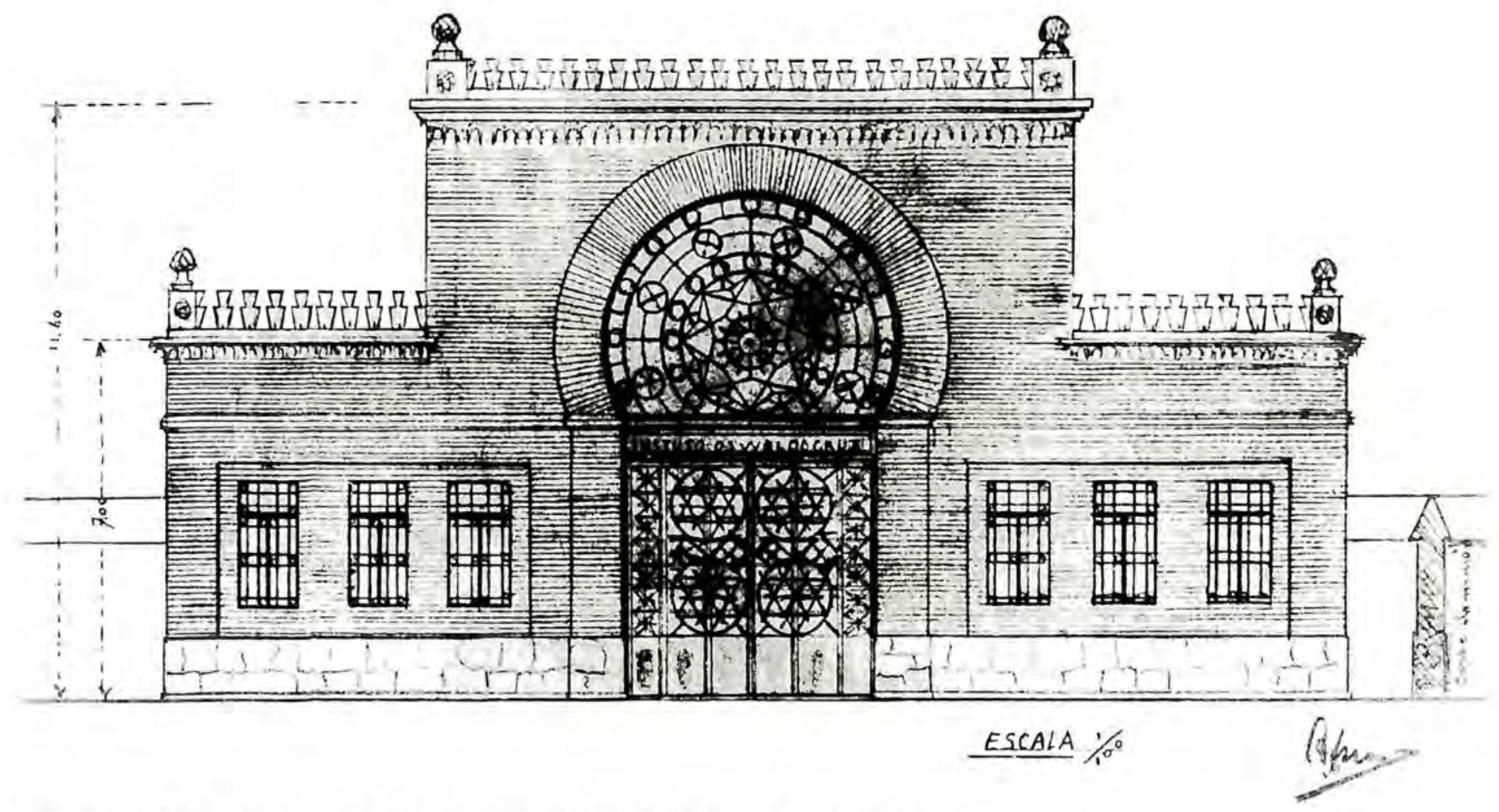

Proposta inicial para a portaria da Avenida Brasil, de autoria de Luiz Moraes Jr., năo realizada. (DAD/Fiocruz)
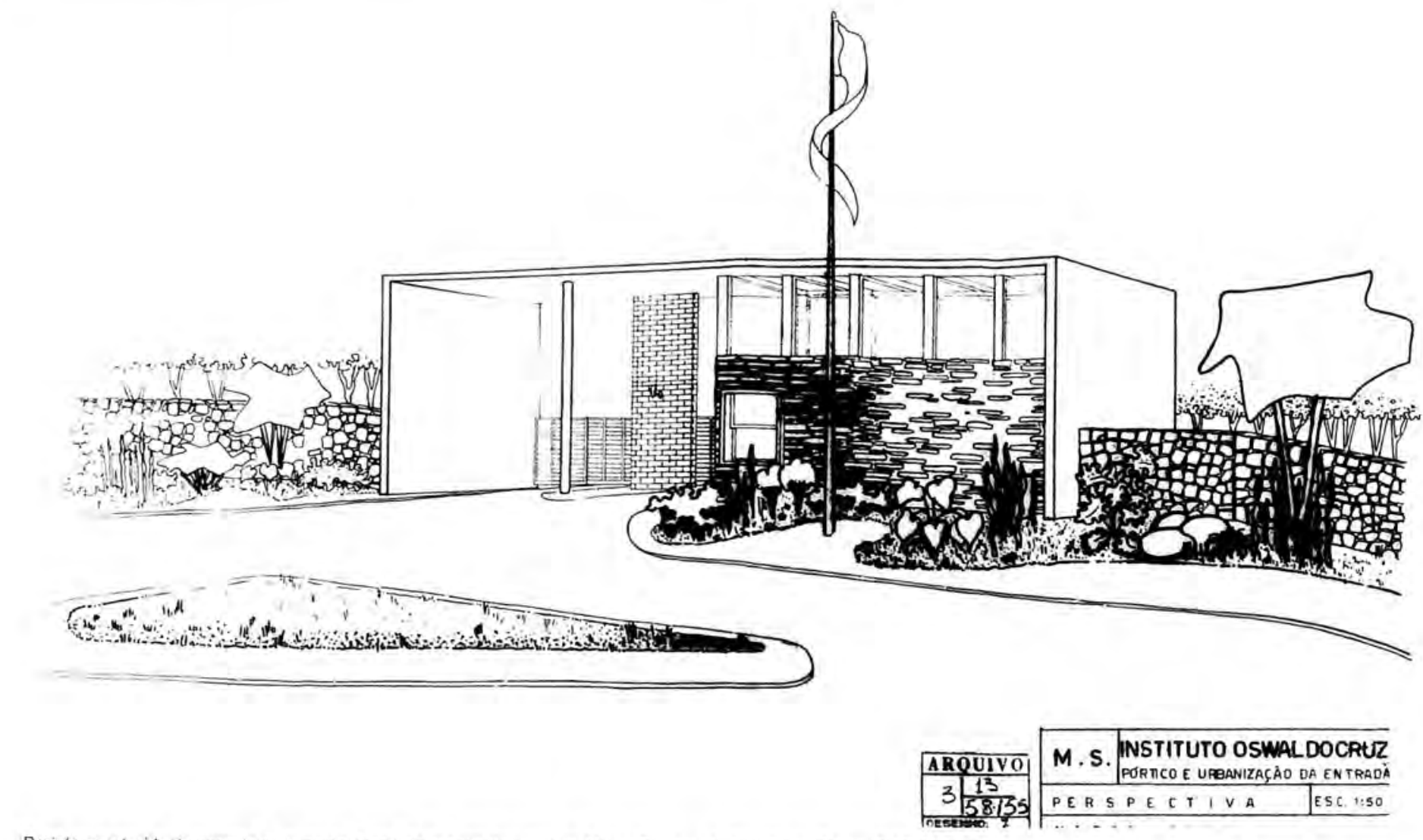

Projeto construido da portaria da Avenida Brasil, de autoria do arquiteto Nabor Forster, da Divisão de Obras (DAD/Fiocruz) 


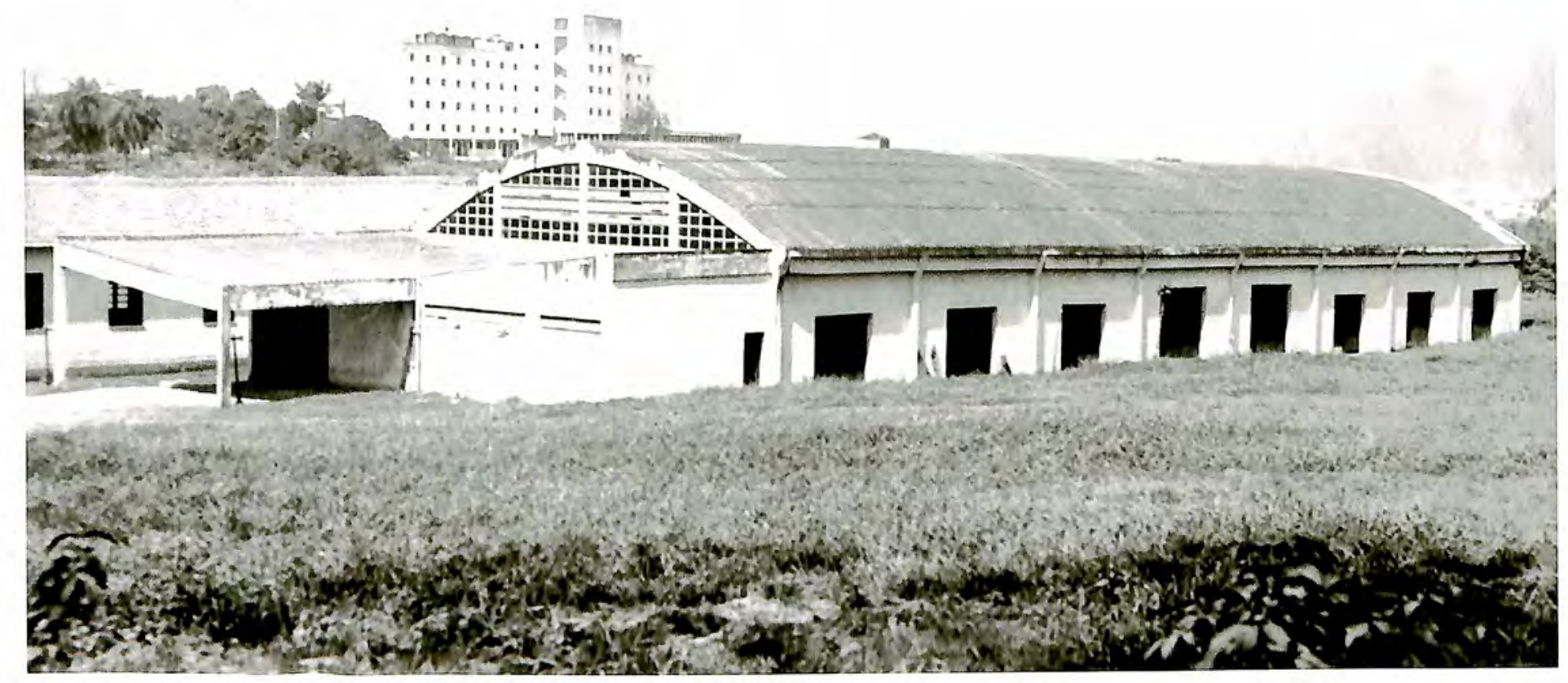

Oficinas e Garagem. Projeto desenvolvido pela Divisão de Obras. (c. 1954). (DAD/Fiocruz)

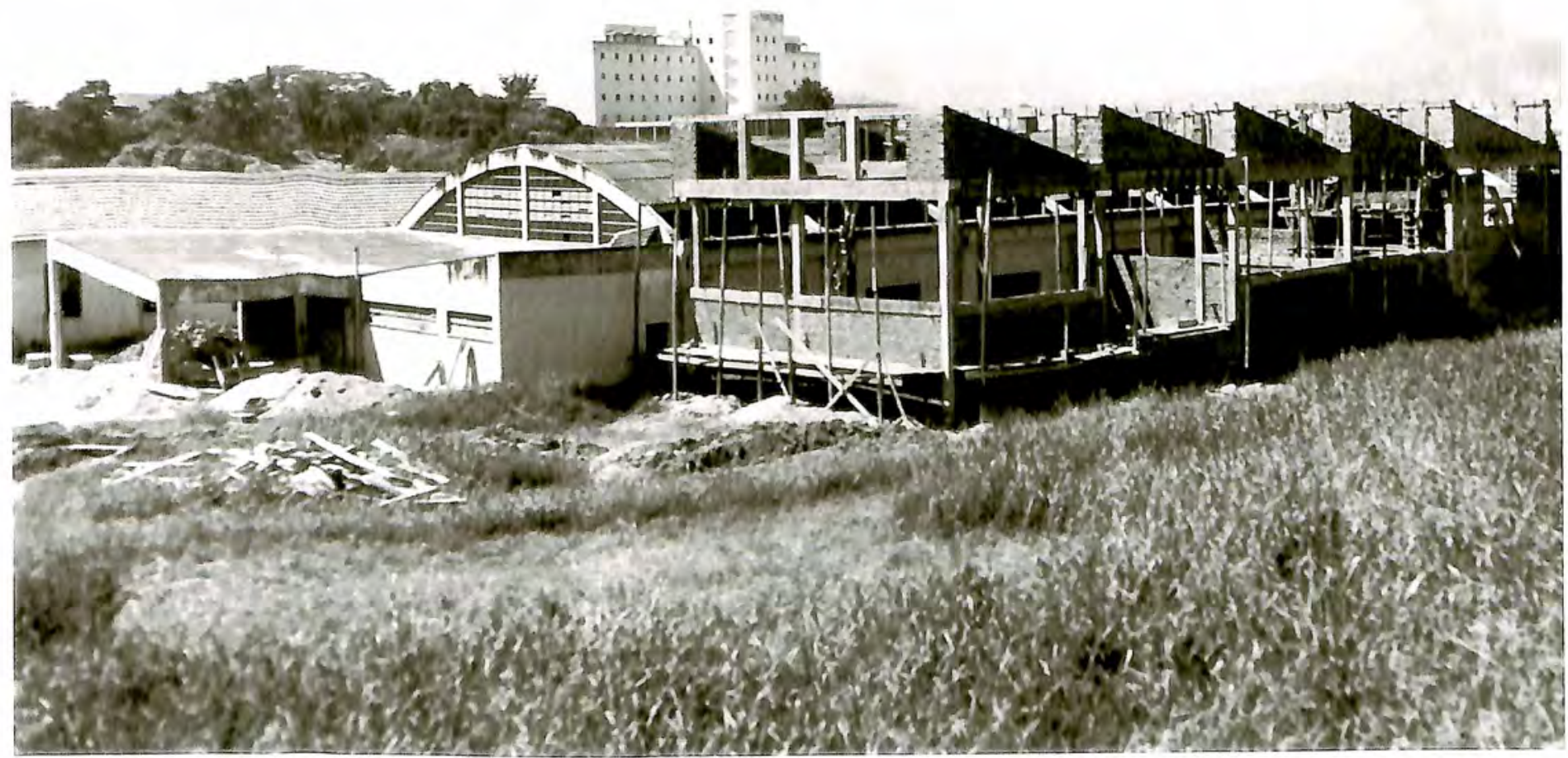

Ampliação projetada pelo arquiteto Waldyr Ramos da Divisão de Obras. (DAD/Fiocruz) 